Article

\title{
Gender and Space during Guatemala's Holy Week: An Ethnographic Account
}

\author{
Karen Ponciano \\ Instituto de Investigación y Proyección sobre Diversidad Sociocultural e Interculturalidad, \\ Universidad Rafael Landívar, Guatemala 01016, Guatemala; kaponciano@url.edu.gt
}

Received: 13 November 2018; Accepted: 17 January 2019; Published: 23 January 2019

\begin{abstract}
At midnight of Sunday, 9 April 2017, the Sunday known as Palm Sunday during Holy Week (Semana Santa), the streets of Guatemala City were packed with parishioners, passers-by, and strollers watching the procession of Jesús Nazareno de los Milagros, "King of the Universe". The procession's itinerary takes almost eighteen hours to complete and it is one of the most popular processions among Catholics in Guatemala. What was I, a female anthropologist taking notes and pictures, doing as part of the entourage of the image of Jesus? The question is not gratuitous because this specific space, namely, the entourage itself, is reserved exclusively for male bearers, the so-called cucuruchos. This ethnographic incursion took place within the framework of an ongoing research project on the construction of gender subjectivities in urban religious spaces in Guatemala City, a project that attempts to answer larger questions on the various processes of subject formation within religious spaces. In this article, however, I will focus exclusively on the construction of gender subjectivities during the celebration of the Holy Week in Guatemala City. This paper discusses how a religious space can be analyzed as a "place of encounter" that will intensify social relations coming from beyond, and going beyond, the processional space itself.
\end{abstract}

Keywords: gender subjectivities; urban religious spaces; Holy Week in Guatemala; Catholic Brotherhoods and Associations; Religious festivities

\section{Introduction}

At midnight on Sunday 9 April 2017, the Sunday known as Palm Sunday during the Holy Week, the streets were crowded with parishioners, passersby, and strollers observing the procession of Jesus the Nazarene of the Miracles, "King of the Universe". The procession had departed at six thirty in the morning from the Sanctuary of the Archdiocese of Saint Joseph, located in the center of Guatemala City. Running a course of almost eighteen hours, this procession summons some of the largest crowds of catholic parishioners. This procession had been organized by the members of the Brotherhood of Jesus the Nazarene of the Holiest Cross of the Miracle. What was I, an anthropologist woman, doing taking notes and photographs from within the cortege of the image of Jesus? I do not pose this question gratuitously because this specific space, within the cortege of the image of Jesus, is reserved for male bearers (the cucuruchos). From this somewhat unusual vantage point, this article thus aims to understand the relation between space and the formation of gender subjectivities during the Catholic celebration of the Holy Week in Guatemala City.

My analysis is based on observations of various processions during Lent and the Holy Week festivities in Guatemala City in which I paid attention to how the space of the processions and the streets is organized and occupied, as well as the ways in which a type of order is demarcated and/or subverted. I also observed the dynamics between men, women, children, families, and neighbors within the processional corteges, the planning and organization of space within the corteges, the relationship with passersby, and the role of municipal authorities. I tie these observations with interviews I conducted 
with people (men and women, either members or collaborators) from Associations, Brotherhoods, and Guilds $^{2}$ that organize the Lent and Holy Week activities in Guatemala City. I focused my interviews on directors and collaborators of the Association of the Church of La Candelaria, the Brotherhood of the Church of La Recolección, the Guild of the Virgin of Sorrows and the Brotherhood of the Buried Lord of the Santo Domingo Church and, finally, the Cucuruchos Seculares ${ }^{3}$ group. During Lent and the Holy Week, I conducted ten short interviews and then, after Holy Week, I met again with six of those already interviewed (three women and three men) for longer conversations.

Taking this mix of ethnographic notes and interviews as my point of departure, I argue in this article, along with Massey (1994), that the procession, as a religious space, can be understood as a "meeting place" that intensifies social relations coming from beyond and going beyond the processional space itself. Moreover, using (Lefebvre [1974]'s 2013); Harvey (2004) trialectic conception of space as my starting point, I also show (a) how, in "absolute space", gender difference is naturalized, normalized, and materialized in and through religious and cultural manifestations during the Holy Week (doing gender); (b) how the processional space itself is experienced, represented, and understood differently by social subjects (performing gender); and (c) how processions produce "out of place" subjects that question, if not permanently at least cleverly, what has been constructed as the norm. In what follows, I will elaborate on how these three ways of conceptualizing the relation between gender and space help us understand processions as "meeting places." I must emphasize that I chose to present those three parts of my analysis separately, but that this does not imply that they work mechanically or disjointedly. Gender relations are by no means "done", "performed", or/and then "undone": they are produced connectedly, which exposes not only the complexity, but also the thought-provoking relevance, of this topic. Therefore, before embarking in this ethnographic analysis ${ }^{4}$, I will first lay bare how I approach the relation between gender and religious spaces theoretically.

\section{Gender and Religious Spaces: Introducing Some Theoretical Challenges}

When I started to conduct research on religious spaces, one of my basic concerns was how to understand these spaces in ample terms, in a way that would not rigidly close off the experience from either the social or religious aspect. It is very difficult to speak of limits and borders when we, as researchers, approach the religious phenomenon. From an anthropological point of view, as Cantón Delgado $(2001,2004)$ and Segato (2008) recall, we cannot speak of religious spaces as strictly delimited because they encompass ways of organizing, as well as systems of meaning. In my research, I therefore explore not only how religious spaces define and produce sexed bodies, but also how gender is performed and (re)produced in them. As we know, both religious and urban spaces are plural and heterogeneous constructs. In this article, however, I focus particularly on how gender is naturalized, lived, and transcended in processional spaces within the context of differential power relations and unequal access to space in Guatemala City.

Lefebvre (1974); Harvey $(1989,2004)$ open, without a doubt, an alternative path in our understanding of space, thereby escaping from the rigidity that equated space with a delimited materiality. Lefebvre proposes an analysis of space based on three categories (Lefebvre's spatial triad): lived space, perceived space, and conceived space. Lived space is, for Lefebvre, the practice of space

2 All three terms (guild, brotherhood, and association) will be assimilated in this article, since the three designate the organization of a group of catholic parishioners devoted to spreading the cult of an image that is emblematic to the catholic pantheon. These groups have administrative and financial autonomy regarding the ecclesiastical institution.

3 The Cucuruchos Seculares collective is not a guild, brotherhood, or association. It is a group of cucuruchos with their own blog, FB page, and radio space during lent, who comment on how they live and perceive the festivities during Lent and Holy Week as a cultural and social phenomenon.

4 This article is primarily built as an ethnographic account. Being an anthropologist myself, I am aware of the lack of theological reflections which I am in no position to present. However, a summary of this paper was presented at an academic encounter within the Faculty of Theology at the Universidad Rafael Landivar in September 2018. The interest in this subject exceeded my expectations. Since then, I have engaged in a fruitful conversation with some of my philosopher or theologian colleagues. 
itself, the one that is closest to everyday life and its most prosaic uses. Lived space comprises the places and spatial groupings belonging to each social formation that can be thought of as situated in a determined time and place. These spatial practices organize and segregate space, thereby making "social space" out if it. Perceived spaces, in turn, superimpose complex symbolic systems on lived spaces so as to codify them. Lastly, conceived space encompasses codes of order, fragmentation, and restriction; codes that aim to establish both ordinary uses and the symbols that organize them (Martínez Lorea 2013, p. 15).

Admitting his Lefebvrian filiation, Harvey talks about absolute space, relative space, and relational space. Absolute space is the fixed space, usually represented as pre-existing and unmovable. Relative space in turn refers to the multiple geometries that are represented within a spatial framework, but also to whom gets to define this framework, who gets to identify with it, and why. Lastly, relational space is associated with the idea that neither space nor time exist outside the processes that define them. This implies that, in space, subjects carry with them experiences they have accumulated throughout their lives, and these experiences are co-present in a specific and defined space-time (Harvey 2004, pp. 96-99). During my ethnographic work, it became clear to me that I had to consider Lenten space from a multiplicity of angels: church spaces, the occupation of the streets, the places assigned to (male and female) parishioners, the religious experience linked to the occupied space, the social imaginaries that permeate the symbols that organize the processional space, etc. In this sense, the trialectic perspective thus helps me to denaturalize the idea of a predetermined processional space not open to the possibility of contestation and change, and instead proposes to conceive this space as always-already open to and affected by the tensions of daily life.

Even if I am aware that both Lefebvre and Harvey propose their trialectic understanding of space drawing from a Marxist criticism of capitalism, I am more interested in this article in applying their trialectic methodology to complement feminist readings about the relation between gender and space (Butler 2004; Bondi and Rose 2003; Bondi and Davidson 2005; Connell 2010; Hooks [1990] 2015; Johnston and Longhurst 2010; Massey 1994, 2005; Massey and Allen 1984; McDowell 1983, 1992) in order to rethink the gendering of religious spaces and subjectivities in and through performativity. I find this trialectic perspective very helpful because it enables us to move beyond binary approaches on gender relations and religious spaces. If gender has been made invisible in the grand sociological theories of religion, feminist theories have provided an entryway for its analysis. However, the way in which the feminist approach in this field has been practiced until now has greatly influenced how the problematic "Women and Religion" is usually constructed. Briefly, in both Marxist and Liberal perspectives, the analysis of this problematic takes as its starting point an understanding of religion as a patriarchal structure that legitimizes masculine interests and thus subjugates women materially and ideologically. The central concern has therefore been limited to the analysis of a problem constructed in the following terms: is religion liberating or oppressive? Does it reinforce patriarchy? Or does it cover it up? This should not obscure the fact that most of the sociological research on religion has been gender-blind (Woodhead 2001, p. 72). For example, in Latin America, studies that made women's roles in religious spaces visible were predominantly studies by a select group of academics particularly interested in studying the Basic Ecclesial Communities (BCE) and the Evangelical Church (Brusco 1995; Drogus 1997; Mariz and Machado 1997; Peterson 2001). These pioneer studies did open the door to methodologically tackling religious change across Latin America by asking themselves, for example, whether or not conversion to evangelical churches was motivated by intra-household dynamics that did or did not put into question the patriarchal order. Yet this perspective is centered on how gender differences are reinforced in certain spaces, ${ }^{5}$ which ultimately legitimizes masculine hegemony. As such, this perspective reduces the analysis of the relation between women and religion to binary oppositions and is therefore insufficient if we want to understand not only how gender is

5 For instance, in domestic spaces conceived as always in opposition to public spaces. 
being done [doing gender], but also how it is being undone [undoing gender]. This is particularly true if we take into account the "multiple religious belonging" that characterizes the Latin American religious field, as well as the impossibility of clearly separating the sacred from the secular (Kong 2001).

To counter these somehow traditional perspectives, I use Massey's (1994) argument against the construction of "spaces of subjectivity" as something stable and essential. As Massey $(1994,2005)$ argues, a place is never just "a" place but also includes the relationships that extend from and toward other places, relationships that get summoned in a given place at a given space-time. Considering processions as a "space of subjectivity" thus allows me to shift the focus away from a simplistic binary understanding of gender and religious identities in order to explore the organization of Lent and the Catholic Holy Week in perhaps more productive ways. (Harvey 2004, p. 108).

\section{Doing Gender: Absolute Space and Difference Naturalized as Norm}

From the Saturday before Palm Sunday ${ }^{6}$ to Easter Sunday, a series of processions take place and run through the streets of downtown Guatemala City with the objective of commemorating some of the moments which, in Catholic religious tradition, are known as the passion, death, and resurrection of Jesus Christ. The participants are organized in brotherhoods, associations, or guilds. During this week of festivities and commemoration, participants carry religious images of the Virgin Mary, Mary Magdalene, Saint John, and Jesus Christ, among others, on big floats (also known as platforms or "andas").

These floats are specially decorated for the season, by the association, brotherhood, or guild of each church. The float is carried by members of the brotherhood in charge of the veneration of the image, but not just anyone can participate as a bearer given that shifts are booked in advance ${ }^{7}$. The musical band closes the procession while the parishioners line both sides of the street. Each float is surrounded by a rope marking the limits of the space that only actors in the cortege can occupy. A cucurucho, who is currently a member of the Brotherhood of the Buried Lord of Santo Domingo, explains the significance of the rope surrounding the Christ's processional cortege in the following terms (see Figure 1): “The rope is very important because it divides the zones, the areas, that have a significance. The rope marks the division between the sacred and the profane. The rope divides the spaces, and women positioned themselves behind [the roped area]". ${ }^{8}$

The organization of the procession itself expresses how space is not an inert and neutral receptacle: the rope cannot be trespassed; the positions are defined inside and even outside of the processional cortege. The procession passes through the city and spectators line themselves on both sides of the street waiting for the cortege to pass. Devoted men wait on the right side for the cortege. The images of Jesus from the different parishes (except the parish of la Candelaria) have their heads turned to the right in such a way that the image on the float seems to be "looking" to the right. As archeologist Méndez Salinas notes, "the eyes of a sacred image work as a magnet", which explains why male devotees occupy the sidewalks on the right side of the street while waiting for Jesus to pass (Méndez Salinas 2017, p. 5). More than an acquired privilege, the male devotees' positioning is regarded as an unquestionable fact. As such, the handling of the rope normalizes a gender division that has been produced as fixed and unmovable.

6 In Guatemala, this particular Saturday is known as "Sábado de Ramos".

7 Given that processions are long rituals that last for several hours, different groups of bearers are formed, taking shifts during the day. The sale and purchase of shifts began in 1897 with the restoration of the brotherhoods of the Churches of la Candelaria and Santo Domingo. See Chaulón (2014) for an extensive analysis of the development of the shift as a commodity.

8 Interview 5 May 2017. I have translated this and all other quotes from my interviews from the original Spanish. 


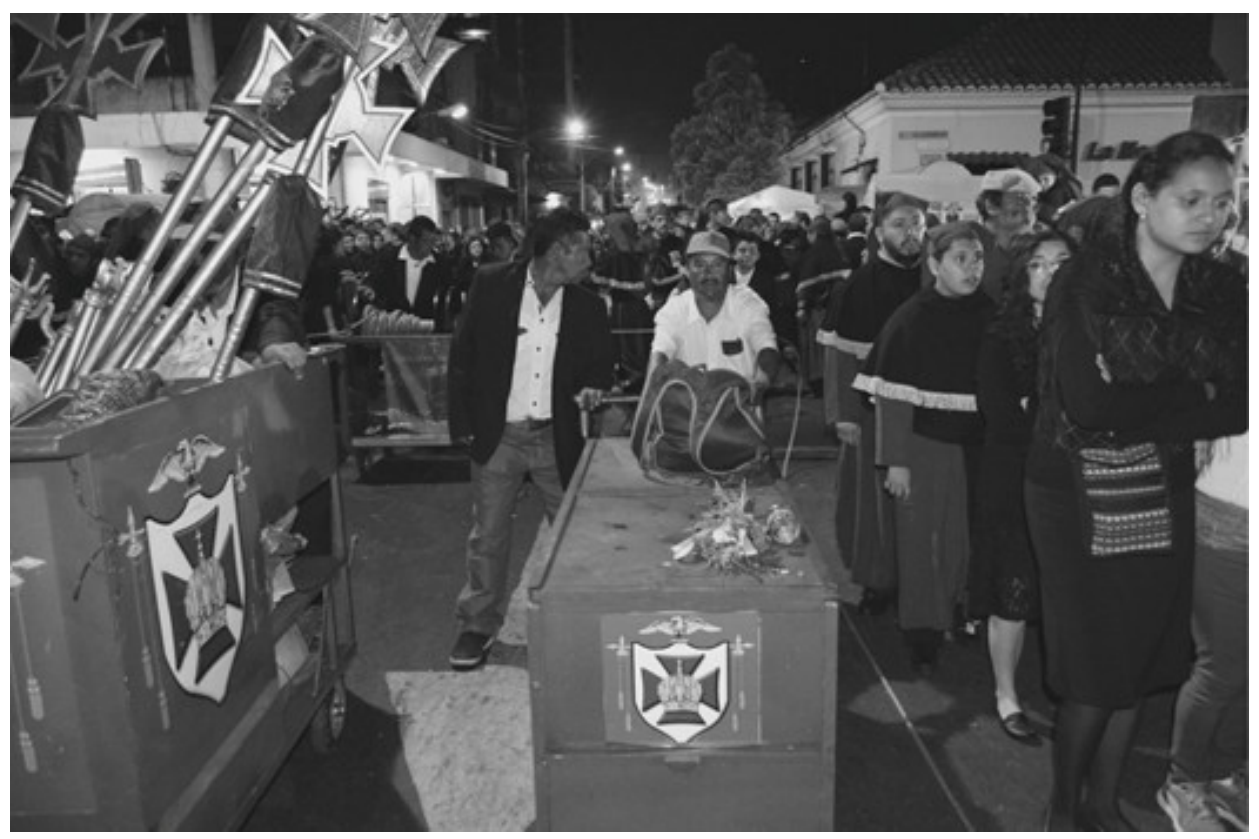

Figure 1. Dividing rope marking the processional area along with box of tools belonging to the Guild of the Rope during the Procession of Jesus the Nazarene of the Miracles, "King of the Universe", Palm Sunday 2017. Photo: Karen Ponciano.

Even if during the procession different and diverse images are the object of devotion, the image of Jesus is nonetheless the center of attention for Catholic parishioners during the Passion. Consequently, the order of the cortege is always the same: first goes Jesus, then the other images, and lastly the cortege of the Virgin (unless the Virgin goes out alone). "Jesus is the center" ${ }^{\prime \prime}$ of the festivity.

The image of the Virgin, which is preceded by two other images carried on small floats, does not awaken that much interest. Jesus moves forward and behind him comes the Virgin. As night falls, the women's cortege gets closer. This is used as a safety measure. At one o'clock on the dot, we arrive at the Temple of Saint Joseph for the floats' entrance, which is awaited by dozens of people. (Field diary, Sunday, 9 April)

Both the separation between the images and the order of the processional cortege itself have been historically constructed as an immutable and natural fact. On the one hand, the women's place is around the Marian figure; that is, their presence is not permitted within the space inside the rope surrounding the masculine figure of Jesus. On the other hand, however, men do hold the job of monitoring and controlling the processional march, even if they do not carry the Virgin. In fact, the helmsperson (the one who directs) of the Virgin's float is always a man. As a female member of the Association of the Church of Candelaria makes it clear:

The female chiefs (of the row) carry radios and, given that we always have a group of men coordinating us, one can ask them for help if there is trouble. We are in charge of certain things (in the procession) but there is always a male chief that can communicate with (the cortege of) the Virgin and (the cortege of) Jesus using a radio transmitter that both (corteges) carry. So he knows if something happens.

As Bondi and Davidson (2005) show, being a woman implies eventually feeling confined and constrained by space. Being part of the procession as a woman thus implies living the experience 
according to a spatial disposition that is masculine by definition. In other words, the processional space privileges masculine subjects and allows them to express and impose themselves within that space. Both the festivities' focus on Jesus' float and the irrevocable order of the cortege give the impression that the processional space does not actually belong to the female bearers; instead, they seem to be trapped and confined by it. In the interviews, they in fact very rarely claim that space as their own, except when referencing the image of Jesus.

Even if female bearers were first incorporated into processional corteges very early in the 20th century, those who define the routes the processions follow have always been, up to this day, the (male) members of the brotherhoods, associations, or guilds of the Passion. Four traditional brotherhoods-those of the Churches of Santo Domingo, la Merced, la Candelaria, and Saint Joseph - try to preserve, despite the introduction of small changes, the routes that were designed in the 20th century. Most other processional routes, however, are modified each year, especially so since the start of the commercialization of shifts and the itinerary's extension due to the increasing amount of shifts being sold. Yet even in these cases, places such as Central Park, the Cathedral, and the National Palace are kept as part of the route given their significance. When trials are done before Holy Week to evaluate if already established routes need to be modified, there is not one woman involved. Moreover, when planning the itinerary, the routes are not only adjusted, but the places that men and women must occupy in the processional space are also confirmed. By not taking part in the configuration of the space itself, women are assigned a place they concurrently occupy as participants and exiles. In this sense, as Moncó notes, even though female participation has made a deep imprint in brotherhoods in general, men still maintain positions of leadership and power, and therefore still hold the most prestigious posts (Moncó 2009, p. 369).

The heteronormative structuring of space is also confirmed through the imaginaries conveyed by the venerated images: the relationship between the parishioners and the images is pierced by diverse vectors linked to devotion and the reaffirmation of male and female stereotypes. As I have already pointed out, the processional cortege is organized around the revered images. The processional path is covered with so-called "traditional carpets" made by parishioners, their families and friends, and neighborhood residents out of flowers, fruits, coyol palm, and sawdust of various colors. These carpets show diverse images of religious significance and, given that they are regarded as offerings for favors sought or already received, stepping on them before the procession has passed is strictly forbidden. As Joan Scott (1996) underlines, these images are culturally identifiable symbols that evoke social representations that have specific meanings in different historical contexts. For example, female bearers and cucuruchos, at different moments and for different reasons, equate the image of the Virgin as representative of femininity with the mysterious, the pure and natural, motherhood, mourning, the feared and the desired, caretaking, sacrifice, and/or pain. One cucurucho, a member of San José Temple's Guild of the Rope, expressed this multiplicity of meanings in the following way:

The Virgins of Solitude will always wear black, we cannot dress them in a different color for Holy Week, or in white when it's not Holy Week. Which is another type of mourning, this one showing her pureness. But in a Holy Week procession they will always wear black, in mourning. And their cloaks usually have stars as a reflection of the firmament that weeps for Christ. Remember that the evangelists say that when Christ dies the skies opens and it gets dark. So, it is the sky that weeps for Christ (...) We respect the Virgin as the mother of Christ. She is the Virgin Mary, the Mother of Christ (... ) The Virgins of Sorrow are important during Holy Week but not as important as Our Lady of Solitude since she's the one that remains alone after the death of Christ. We must give her our condolences. If you analyze all the iconography of the Renaissance ( . . ) it's all about recovering the figure of the Virgin Mary receiving the corpse of Christ, the dead son. Jesus had told her on the cross a 
few hours before [dying]: "son, behold your mother; and mother, behold your son". Do you remember that scene?"10

The lonely, selfless, and mourning mother characterizes, as I will show below, one of the ways in which femininity is symbolically established. As I noted above, processions would not exist without the images. In fact, identification with a given guild, brotherhood, or association is almost always constructed in reference to the revered image (the Virgin of Sorrows, Jesus the Nazarene of la Candelaria, the Buried Lord of Santo Domingo, the Virgin of Solitude, etc.). What is more, rituals involving the maintenance and dressing of the revered image, as well as the decoration and caretaking of the floats, are always part of this process of identification. It goes without saying that in these rituals, gender differences are also present at different levels. In the interviews I conducted specifically about these rituals, the male and female bearers emphasized, above everything else, the preparation of the garments and the process of dressing the images, which is an exclusive and private activity. It is indeed a selective circle since, for example, it is not allowed for a man to "dress" the image of the Virgin and therefore see her "naked". Regularly—and this is an unwritten norm, but one that's observed by the majority of participants during Holy Week rituals-women and gay parishioners (the latter not acknowledged by the institutional church) are the ones who are assigned to the decoration and dressing of the Virgin's float. In this sense, gender asymmetries are conveyed through the images in the processional space, which can thus be conceived as a "gendered space" in the sense that "differentiated practices or settings/surroundings, which are strategically used to shape identity, produce and reproduce asymmetrical gender relations of power and authority, are operated" (Löw and Lawrence-Zúñiga 2001, p. 7). As such, the ritual surrounding the images, just as their position in the processional order, reflects a hierarchical representation of gender relations. The usual work of taking care of the image, and cleaning and decorating the church, which is deposited in the hands of women, is another example of the sexed distribution of roles and tasks among male and female members of the brotherhoods, guilds, and associations. This distribution comes from beyond the processional space as a meeting place; that is, it reproduces and normalizes gender stereotypes or constructions already existing in society. So much so that, in many cases, it is evident that women have been included only because they are indeed needed by those men who do not regard caretaking, cleaning, and decoration as part of their roles within and beyond the processional space.

In reality, the normed space of the procession enables gender hierarchization from the moment in which it positions women in an other place, thereby reinforcing dichotomous discourses and essentialist understandings of masculinity and femininity. Specifically, the image of the Virgin as the ritual's cornerstone mediates a representation of femininity linked to motherhood as a community code, thus underpinning and giving continuity to the imperative and dominant model of motherhood (Moncó 2009, p. 382). It is in this sense that I argue that the normalization and reproduction of relationships based on a traditional conceptualization of gender roles comes from beyond the processional space itself, thereby allowing us to understand processions as "doing gender".

This argument also implies that social relations associated with doing gender are not contained exclusively within the processional space, but rather go beyond it. What needs to be noticed is, ultimately, the difficulty of conceiving the processional space as a localizable and closed entity given that the social relations that constitute it come from and extend beyond its borders (cf. Massey 1994, p. 162). Accepting the contrary would mean understanding the processional space in static and encapsulated terms, and thus as immune to change. It would also mean calling into question the very concept of processional space since the sense of space (cf. Harvey 1989) is subject not only to how the procession itself is thought of, inhabited, and experienced, but also to how social relations exist in and through space within a complex network of articulations and interconnections (cf. Massey 1994, pp. 162-68). I would then argue, along with Kong (2005), that beyond this normative depicting of the

10 Interview, 19 May 2018. 
processions, it must be stressed that there is no other space at a certain level of social and religious life, however transiently it might be, where large numbers of men and women meet who would otherwise never have come into contact. [ ... ] Therefore, the processions function "as occasions on which communitas is experienced and as journeys toward a sacred source of communitas which is also seen as a source of healing and renewal" (Kong 2005, p. 3) The dynamic nature of these relations is, in fact, what will allow me to consider and reflect upon how gender is performed in the processional space in the next section.

\section{Performing Gender: Relative Space or how Processional Space Is Represented and Lived Differently by Social Subjects}

Besides the already described posts and the bearers of the floats, a variety of members of the brotherhoods can be found within the roped area. These serve different functions that in one way or another make sure that the procession passes in an orderly fashion and the established route and times are respected: the general inspector, the inspectors and female chiefs of rows, the auxiliaries, the watchmen and women ${ }^{11}$, those in charge of the shift changes, the spiritual commission ${ }^{12}$, doctors and paramedics, the Sayones (those in charge of the rope), the "rompevías"13, the band inspectors, the float guides, and those who carry the poles that are used to raise the street light cables, among others. Each position represents a given job, and each person takes their place and makes it their own. In the narratives constructed by those interviewed, the perception of the procession depends on the place each occupies. Even if the cortege's route is meticulously designed and the places are previously assigned, those who are actually part of the procession are the ones that naturalize both the cortege's route and the places they occupy: they represent them to themselves not only as a symbolic place, but also as what produces their identity as a cucurucho, as a female bearer, etc.: "Once I had to carry on the right side. I always bear on the left side. If I'm not on the left side it's as if I had not carried at all, as if the cucurucho were someone else." ${ }^{\prime 14}$

The space becomes socially relative; in other words, the experience of the Holy Week scene depends as much on the position that one occupies within the cortege as on the multiple neighborhoods the procession passes through and the brotherhoods that organize the event (stage and procession). As a member of the Santo Domingo Church's Brotherhood of the Buried Lord eloquently explains it:

The Barrio Moderno, the Barrio of la Candelaria or the whole part of First Avenue in Zone 1 are not the same. Each place within an area experiences it differently. In some it's more a family celebration, in others a commercial one, in others it's more solemnly, in others more festive. It depends on the place. Being in such a tiny place, you see it differently. And even more so if we go through each procession and each brotherhood, their vision differs completely from one another. They do resemble each other, but there are substantial differences in the details. ${ }^{15}$

In this space of socialization, the (re)production of gender difference is lived differently, depending on the role or position people occupy in and during the procession. In this article, I simply note that the distribution of duties and positions is also marked by gender. In the assignation of positions, hierarchical order (which positions are considered positions or shifts of honor and which are not; which positions are considered to be more or less prestigious, how is class privilege linked to them, etc.) does play a role, but gender relations also do. The fact that specific places are assigned to men and women not only implies being explicitly bound to a certain place, but also means that, by occupying

11 Watchmen and women are in charge of interacting with the cucuruchos, bearers, and other people taking part in the cortege so as to ensure order and coordinate the movements of all those participating in the procession.

12 This commission is made up of those who pray with the cucuruchos and bearers before their turn to carry the image.

13 The "rompevías" are those in charge of removing any obstacles on the procession's route.

14 Interview 10 March 2017.

15 Interview 5 May 2017. 
that given space, a gender division is naturalized, even if individuals inhabit that gender division in particular ways. It is indeed important to occupy that space. However, it is equally important to impeccably fulfill the heteronormative functions of that space: "It doesn't matter if I'm gay, I assume the role I'm given for the procession." 16

Women always notice the existence of an explicit separation, but they do claim a protagonist position in their narratives when referring to their role in coordinating and organizing the cortege of the Virgin's float (see Figure 2). Even if there is a general inspector, in the street space where they actually are bearing the float, the organizational rhythm is set by female participants such as the chiefs of row, the auxiliaries, the wardens, and the members of the commission in charge of shift changes, which includes a general manager and two sub-managers on the right and left sides-just to mention a portion of those involved. However, when they talk about the shifts, the female bearers that were interviewed recurrently mention that, as a general rule during Holy Week processions, they cannot carry Jesus' float. ${ }^{17}$ As a gay ex-cucurucho makes it clear:

Why must women only carry the Virgin? And why must men only carry Jesus? Aaaaah, but men are given the opportunity to carry the Virgin. Makes one say Jeez! But then why doesn't it happen the other way around? In the Reco [Recolección Church], for example, when they go out on Holy Saturday, men generally have that opportunity. If there are men who feel a greater devotion for the Virgin they're not left with the desire, they can carry her. ${ }^{18}$

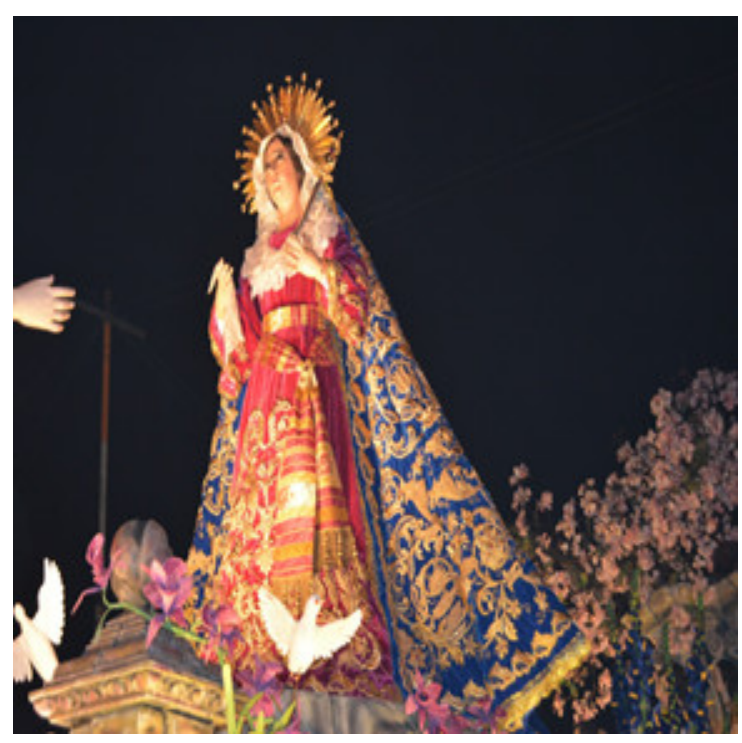

Figure 2. The Marian image in the procession of Saint Joseph.

Or, as a female member of the Association of the Church of la Candelaria succinctly puts it: "Who doesn't want to carry Jesus? One's beloved Jesus?"19 As these examples show, non-male bearers are indeed aware that the place assigned to cucuruchos is a privilege that is denied to them for not being male. It is not a question of faith or devotion, but a question of gender:

In these past years, there have been shifts for men to carry the Virgin during Holy Week, as much so during Lent as in Holy Week, there is this tendency: they have special shifts for

\footnotetext{
16 Interview 10 March 2017.

17 Rare exceptions have been introduced over the last years though. For example, on the morning of Good Friday, the Church of La Merced sells some shifts so that women can carry the image of Jesus.

18 Interview 9 May 2017.

19 Interview 24 April 2017.
} 
men, giving them a bit of prominence within the women's corteges. Sadly, it's a bit harder for us as women. We even see this in the brotherhood. There are married women who have no one to take care of their children, and this forces them to leave very early, before the entry, or to not take part anymore, and the same thing happens in the processional corteges. It happens often, women who ask for early shifts, you know, depending on the size of the procession, late morning, for the same reason, right. Whether it's because of transportation or their children's care. This allows men to start taking over their shifts, because they do stay until the entrance of the procession. So this has happened. We are trying to avoid this, at least for the more important corteges, the ones on Saturday and Friday, to give that space to women, to the devoted female bearers; to give them that special time so they can be with the Virgin. The brotherhood has also received letters, requests, from men requesting shifts, but we stand our ground in that those two corteges are for women only. ${ }^{20}$

Meanwhile, the cucuruchos interviewed do not perceive that distinction as a privilege, and they do not make reference to the Virgin's float if not asked directly about it. When they talk about positions of privilege, they refer, instead, to the more prestigious shifts (those that allow the cucurucho to carry the float while passing through emblematic places of the city center or when the cortege leaves or enters the church and which are therefore more expensive). It is thus interesting to note how, despite this, women not only assume their assigned places and produce them with their gestures, clothing, and ways of interacting within the cortege, but also insist on maintaining the processional order. Besides, even when they assume their place ("my place is with Mary, my place is not with Jesus"21), female bearers, as well as members of female guilds, brotherhoods, and associations of the Passion, accept their place as subordinated to the devotion to the (masculine) image of Jesus. In this sense, it is interesting to note that the gender division made by the rope is performatively brought to life by the female bearers, thereby solidifying and reproducing this very same division. In fact, according to the responses of the interviewed female bearers, it is important, for order's sake, to maintain already established positions within the processional cortege. Therefore, female bearers not only willingly confine themselves to their assigned space, but also produce and reproduce the established order by demanding that the margins or limits traditionally determined for men and women be respected because, as a female member of the Association of Candelaria emphatically notes, "that's the rule":

Something peculiar happens in Candelaria: men cannot go into the women's line and women cannot go into the men's line. It's not allowed! We have to go with the Virgin. In all the other processions they tell you "step out or have her walk next to you but on the outer side and there one goes walking". But in Candelaria it's not like that. I know this well since I'm in charge of this, my position being chief of the right row. This means that I am in charge of a group of about fifteen wardens, who are the ones who go along looking after those in the rows. And they are instructed that no man can be in the row, even if he tells you that he's accompanying his mom, sister, cousin ... It doesn't matter. He has to wait for her on the sidewalk or in the back, or they meet up further ahead, but please, he cannot go in line. That's the rule. ${ }^{22}$

Conversely, during my field observations, I was surprised by the increased significance of the images of Jesus in the Holy Week processions as a performative symbol of masculinity in this religious, social, and cultural context. Then, when interviewing and listening to men from different brotherhoods or just collaborators, I realized how they were structuring their narratives: in their accounts on how they lived the Holy Week festivities, not only did they gradually recreate the ritual's

20 Interview 24 April 2017.

21 Interview 8 May 2017. Interview with a woman member of the Guild of the Virgin of Sorrows, Church of Santo Domingo.

22 Interview 17 April 2017. 
discipline, the distinctive signs of the Catholic celebration of Holy Week, or the elements marking their participation in such celebration, but they also constantly referred to specific forms of masculinity, mostly through body language. The design of religious spaces defines and produces sexed bodies and ways of living gender. For instance, cucuruchos know that the body must show the marks of having participated in the Holy Week celebrations: bruised shoulders, physical wear, and sweating during the procession relate to a sense of masculine pride. Suffering and resisting pain, and hunger and thirst during the procession are also repeatedly pointed out by male bearers as a sign of virility, just like being impeccably dressed in their tunic and other pieces of the cucurucho's trousseau (see Figure 3). In some cases, the tunic is an heirloom from the father or grandfather, which is why they also talk about (re)connecting with their ancestors' tradition when wearing the tunic. By wearing the tunic, the idea of masculinity is thus combined with a feeling of sacredness that is part of a penitential manifestation. As a cucurucho, a member of the Temple of Saint Joseph's Guild of the Rope, explains:

The ritual or tradition is that I pick them up at their house, the three of us head out, usually in my car, and we leave it in a parking lot near Santo Domingo, so Don Cayetano can walk, but the ritual of dressing up takes place in that parking lot. I've filmed them on another phone. Alberto dresses him with lots of patience, puts on the belt, the tunic, everything. The ritual of dressing up is important. Don Cayetano kisses his robe, says a prayer, puts it on, puts on his award medal ... To me, the tunic represents being able to enter the ritual, being able to be within it, and also being able to assume my identity: the cucurucho identity. Which is also assumed as a tradition. I'm using this dress code that makes me reconnect with my ancestors.... This reconnection with my ancestors, being able to be there, being able to wear it once a year, and there are other people like F.B. that consider it a formal dress. Fernando says "bury me wearing my tunic". I know many cucuruchos who say that this is a sacred costume, a costume that allows me to be close to my image. It is a costume that, if I'm going to wear it, must be worn as an example of conduct, of being. The cucurucho is assuming a penitential costume. Because I'll tell you something, the tunic is warm to wear, carrying all that for so many hours makes you really hot and you want to take it off. ${ }^{23}$

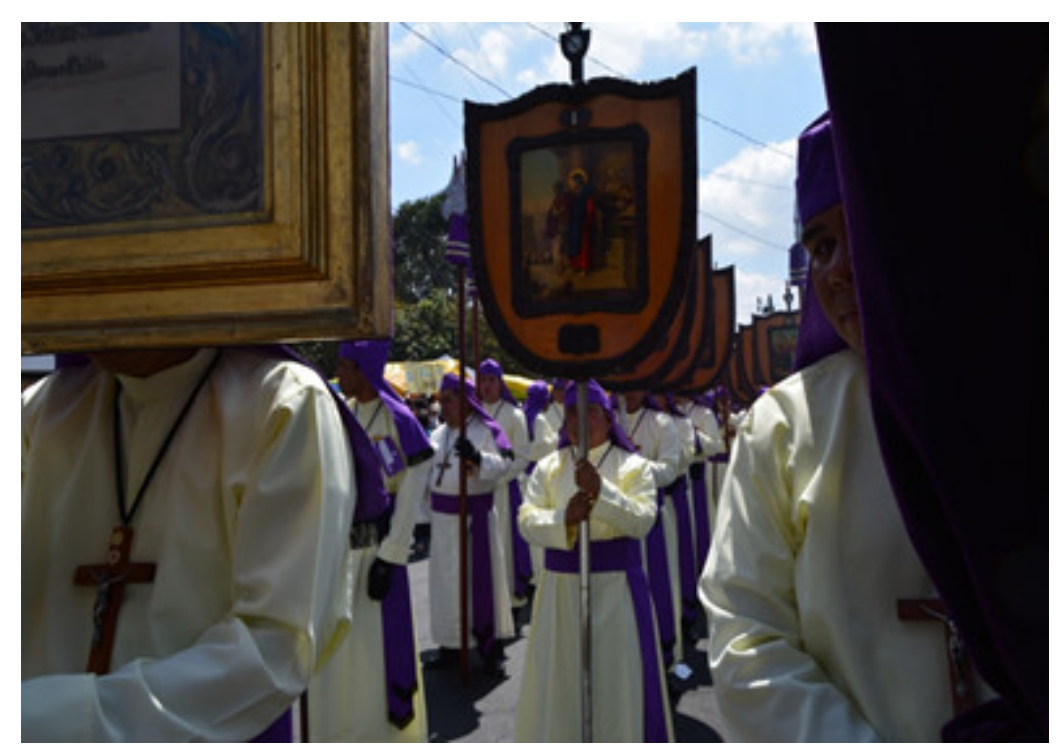

Figure 3. Cucuruchos in the procession before Palm Sunday, departing from the Temple of la Recoleccion. Photo: Karen Ponciano.

23 Interview 11 May 2017. 
Another element that I observed during fieldwork was the personification of the character of the Roman escort ${ }^{24}$, which denotes the expression of a type of hypermasculinity based on physical strength-note, for instance, in Figure 4, the marked pectorals on the Roman character's outfit. This hypermasculinity can be read as a quasi-military, disciplinary spectacle or performativity associated with the imaginary of the Roman legion. The Roman also performs a sort of virility linked to strength, which is proudly displayed in the processional space. Indeed, men justify not letting women carry Jesus' floats because these are bigger and heavier than those of the Virgin and therefore require more strength and endurance. Physical strength as a natural biological condition is thus present in the gender differentiation that everyone involved with the processions reaffirms in their narratives of them. Indeed, this space is not only a devotional refuge: "one goes there to see and to be seen." 25

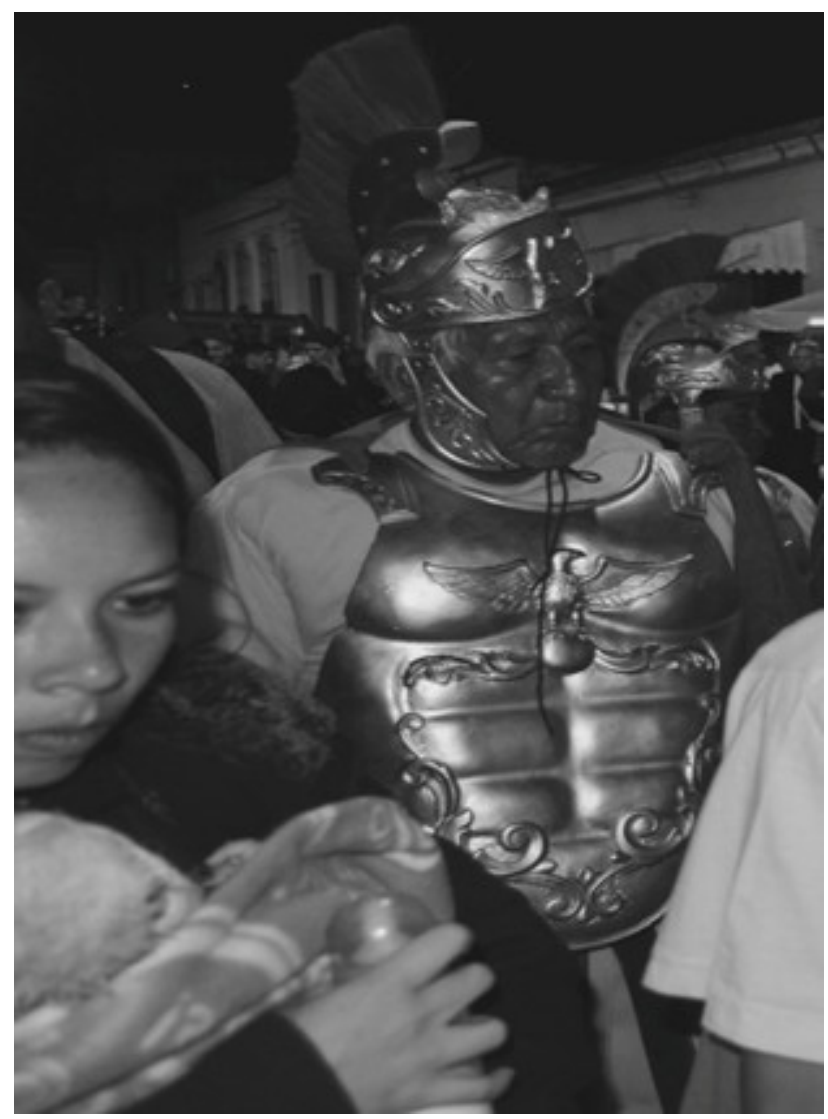

Figure 4. Roman Character during Palm Sunday, 2017. Photo: Karen Ponciano.

Another interesting aspect of gender performativity is how the devotion to images (a devotion that varies according to the person interviewed) is translated into diverse gender subjectivities. If we think of the devout as an offeror, the offering or devotion is also segmented according to gender identities, such as the cucurucho's preference for certain suffering images of a naked Jesus, the devotion of gay men towards the Virgin of Conception, the cult of the Virgin's femininity, and the exaltation of the imaginary of motherhood associated with the Virgin, which, as we will see below, contrast with the attraction that Maria Magdalene's images generate.

24 The Romans, as they are popularly known, form the escort guard that precedes Jesus' float during the procession of Saint
Joseph on Palm Sunday. These characters were introduced in the mid-20th Century to attract more spectators. 25 Interview 9 May 2017. 
In Table 1, I have listed the main epithets associated with three key figures venerated during the Holy Week celebrations. An in-depth semiotic analysis of the images goes beyond the scope of the ethnographic discussion that interests me here, but I would nonetheless like to point out three important aspects associated with these epitaphs in relation to gender performativity.

Table 1. Main epithets associated with key venerated figures.

\begin{tabular}{ccc}
\hline Jesus & Mary & Mary Magdalene \\
\hline God & Mother of Christ & \\
Father & Virgin & \\
Lord & Immaculate & The Cucurucho's Girlfriend \\
King of the Universe & Of Solitude & Wife of Christ \\
Jesus of the Three Powers & Of Sorrows (the "chinita") & \\
& Spiritual flower & \\
\hline
\end{tabular}

First, it is interesting to note the strong contrast between parishioners' perceptions when they name the Virgin Mary or Mary Magdalene. Both are subjects of devotion, but the former has been associated with the image of suffering and sacrificial motherhood, torn apart by the loss of her own flesh and blood, whereas the latter is associated with the idea of the woman as an object of desire, which explains why she is commonly referred to as the "Cucurucho's girlfriend". Both images form part of an imaginary that (re)structures the relationship between devotion and subjectivity in terms of desire and through the vectors of sex and race. The racial vector is clearly expressed by interviewees (especially cucuruchos) when they exalt the whiteness and Spanish features of the Virgin Mary, while at the same time noting the resemblance between the image of Mary Magdalene of the Temple of la Recolección (see Figure 5) and the female bearers, who are overwhelmingly non-white. During Holy Week, there are even competitions to choose who is the female bearer that looks most like Mary Magdalene and therefore, the "most attractive". In contrast, the beauty of the images of the Virgin Mary is judged following a different set of parameters. As a gay former cucurucho explains:

When I see the cucuruchos talking amongst themselves about the beauty of the Virgins to see which one's prettier, you always hear them talking as if they were referring to a mother. Ah, yes, that's the prettiest one ... But on the other hand, this one, Mary Magdalene, who is not the Virgin, now that's another thing. It begins as a competition between the images of the Magdalenes from different churches. So, the image of Mary Magdalene form la Recolección, everybody knows that she is the prettiest one of all the images of Mary Magdalene, and that's why they call her the Cucurucho's girlfriend. And that's when I say, how can you call a saint your girlfriend! Because in the end she is a saint, but since she is Mary Magdalene, the one who was a prostitute and was converted, and is now doing penance and following Jesus ... I feel like that's where all these ideas start to run into each other. And then they say: yes, that's the Cucurucho's Girlfriend, guys, she's the cutest. And everyone accepts it. You ask people, who's the Cucurucho's Girlfriend? Ah, the Mary Magdalene of la Recolección. And she even has a story: a sculptor was in love with a girl that lived around there, but she was high-class and never paid him any attention, so he made her into a sculpture and left her there. ${ }^{27}$

26 This virginal image is known as "la chinita" or "the little Chinese Virgen" in reference to her slanted eyes.

27 Interview 9 May 2017. This ethnographic observation opens the door to further analysis on how the Marian traditions have been constructed in this specific context by considering, for instance, how various aspects linked to the femininity of the Marian model are actualized in the processional space and therefore made constitutive of the devotion-subjectivity relationship within this religious context. Due to space constraints, I will, however, limit my analysis in the next paragraph to the role played by what can be called 'the willing maternal figure' in the devotional relationship with the image of the Virgin. 
A second interesting aspect associated with the use of epitaphs in relation to gender performativity is the recurring allusion to the Marian figure ${ }^{28}$ in relation to motherhood and the idea of fertility as something sacred. Devotion is also expressed in terms of searching for "protection for what you carry inside you." ${ }^{29}$ I already discussed in the previous section the theme of motherhood and how it is performed through the image-devotion-subjectivity relationship. What interests me here, however, is highlighting the fact that the Marian images reinforce the notion of fertility as a feminine attribute. In this sense, gender is performed in permanent negotiation with a normative construct that regards "being a mother" as the ineludible manifestation of "being a woman".

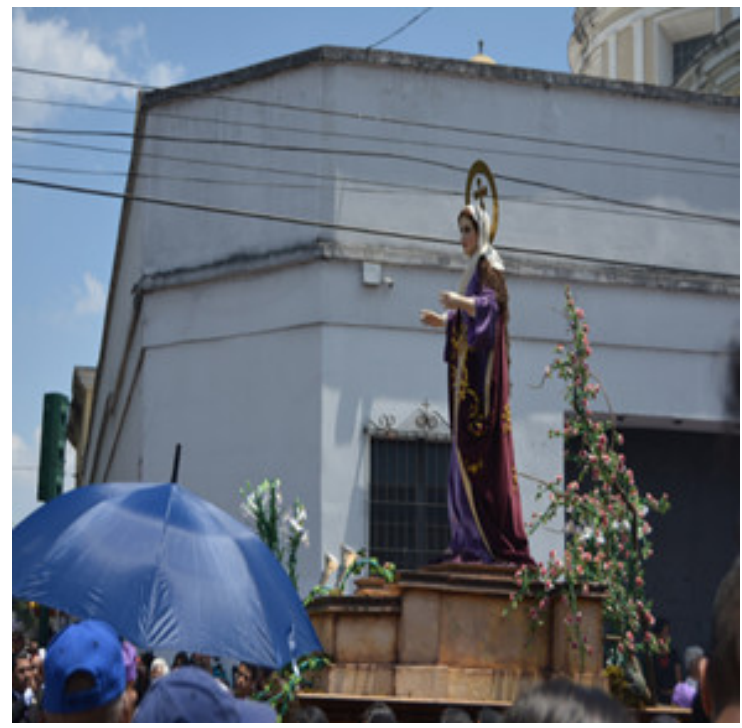

Figure 5. Image of Maria Magdalene of the Church of la Recolección. Photos: Karen Ponciano.

It is not unusual to find pregnant women carrying floats in the corteges, despite the fact that processional routes are long, with infrequent pauses, and shifts taken under the scorching sun of the Guatemalan summer. Most corteges provide medical assistance teams for bearers that faint, get dehydrated, or have an incident during the event. The probability of suffering an incident like these is obviously higher for pregnant women, but they insist on participating:

This year, five pregnant women were going to participate again in the procession. Five months, six months, three months pregnant. I was in charge of a warden, it was her first time, the woman was about six months pregnant and I was taking care of her, checking how she felt. She only left to have lunch and at night she stepped out to have some coffee and when we were already close to the church I told her to go inside and look for a place to sit, but the lady stayed there. For the entire route. I asked her: 'Dear, how do you feel? You're not too tired? Do you want to go to the bathroom? Are you hungry? Have you had any cramps?' Because obviously ... this was the year of pregnant women I felt bad because one who has already had children knows how tiring it is. ${ }^{30}$

When I asked the pregnant bearer why she insisted on carrying despite the risks involved, she highlighted not only that she was asking for protection for the child she had in her womb, but also her deep identification with the revered image of the Virgin as a Mother: "only a woman or a mother

28 When I talk about the Marian figure, I refer exclusively to the different representations of the Virgin Mary and not to the representations of Mary Magdalene.

29 Interview 4 May 2017. Interview with a pregnant bearer, Church of Santo Domingo.

30 Interview 23 April 2017. 
can understand what I feel, she will know how to protect it." ${ }^{31}$ As Moncó (2009) points out, in the act of carrying the Mother, a communal motherhood is performed: the female bearers are united within the context of Lent in a situation of extreme pain (a mother losing her child), and by joining in her experience, the female bearers accompany the Virgin-Mother "making her their own while at the same time equating themselves to her, thereby forming a group of members that are identical to one another and therefore interchangeable. The group seems to be motivated by a common objective: to keep each other company, to take care of each other." The Virgin is thus The Woman alongside other women: "she is not just the Woman accompanied by other women; she is the Mother in the company of other mothers, present or future" (Moncó 2009, pp. 378-79, my translation). One may say that the corteges reflect traditional gender constructions of Catholicism in the Guatemalan context, but one should not take itfor granted that it is always a "problem", especially for women, as I try to explain in the last segment of this article.

The subtle and singular production of relations among women in these spaces often passes unnoticed. Even though heterosexuality and gender difference permeate such spaces, the bond created among the female bearers by their identification with Mary is often dismissed as reinforcing heteropatriarchy. I found, nonetheless, that their religious devotion provides these women with a common shelter "where they learn dignity, integrity of being and where they learn to have faith". (Hooks [1990] 2015, p. 77).

The third and last aspect I want to note regarding the use of epitaphs in relation to gender performativity is the centrality of the images of Jesus during the Holy Week celebrations. More specifically, I found it remarkable how cucuruchos referenced these images as part of the process of spiritual identification with the Passion of the Christ. In the various images of Jesus, different expressions of virility are displayed, that contrast with the representation of the humiliation and crucifixion of Christ. As my informant, former cucurucho, explains:

The man must be strong, he must show that he is suffering or, rather, that he can suffer but endures it, right? What we call ... oh, it's a very interesting Lenten word ... penance! The blessed penance. Penance: You have to take all the pain that comes throughout all this sacrifice that you make by standing under the sun, walking for hours, praying, fasting, and all these things that should bring you closer to God, right? Or bring you closer to the pain that Christ felt on the cross ... So the more one suffers, the better. What's interesting is that on Easter Sunday there's nobody. I don't know if you noticed it, but no one goes. On Good Friday there are five or six processions here in the city center and at the same time, and also on Saturday. But on Sunday: nobody.

The glorification of Christ evokes a symbol of triumph and of rising from subjugation and death - both implicit in the penitential gesture. Multiple expressions of sociability, hierarchy, and masculinity can be exercised through the identification with the staging of the Passion of the Christ during Holy Week (Driessen and Jansen 2013, p. 93). Placing the image of Christ at the center of religious festivities shifts the devotion of Marian images towards the masculine subject. As Fogelman (2006) points out, despite the devotion bestowed upon the Mother, the Marian cult is fundamentally Christ-centric given that it ultimately seeks to glorify the Son and emphasize his exceptionality from the very moment of his incarnation and virginal birth. As such, the worship of Mary, as Fogelman concludes, is in fact praise of the figure of Christ.

To sum up, it can thus be said, paraphrasing (Hooks [1990] 2015), that the processional space is not just one place: it is locations (in plural) both producing and produced by the multiple and changing performativity of gender. ${ }^{32}$ Representing processions merely as a space that nostalgically brings together religious traditions and gender relations understood as they have always been, actually

31 Interview 4 May 2017.

32 Hook's original quote reads, "home is no longer just one place. It is locations." (Hooks [1990] 2015, p. 227). 
precludes us from seeing that such traditions and relations are constantly produced and reproduced in the processional space itself. This is achieved in different ways; above, I have explored five: (a) how "penitential" or "physical strength" masculinities are performed; (b) how the performativity of femininity is linked to motherhood as an element of Marian devotion; (c) how marks on the body acquire a particular significance and provide a particular sense of gender; (d) how the division of spaces is exerted in the order of the cortege; and (e) how the sense of place that each participant produces depends on the position occupied in the cortege.

\section{Undoing Gender: The Production of the "Out of Place" or how Subjects Also Question the Norm}

Even if processions are "meeting places" where gender is done and performed, there are practices that are "out of place"; that is, practices that transgress gender rules and normativity, and that can therefore be conceptualized as "undoing gender". I am referring to people who, because of their devotion to a sacred image that does not correspond to the gender or the place assigned to them, seek to live their devotion by subverting the norms. This is the case, for instance, of women who, risking being expelled, flatten their breasts, wear male attire (that of the cucurucho), buy their shift under a male name, or get a shift from a male friend or relative so as to be able to carry the image of Jesus that they worship. ${ }^{33}$ There are also collectives of devoted gay men whose devotion for the Virgin is such that they have formed alternative groups to the brotherhoods of the Passion, working in parallel with these, but with a similar structure for the preparation of Lent and Holy week. In a different vein, trans parishioners are a demographic that has been invisibilized in the space of the Holy Week celebrations. For instance, they want to be bearers of the Virgin's float, but are constantly denied the possibility: "How could they carry the Virgin! They're not even women!"34 The banning and disqualification rely on trans parishioners not conforming to the requirement of "being" women within the traditional biological imaginary that associates sex with a differentiated and dichotomous biological demarcation. Trans bearers thus inhabit a liminal space of ambiguity that is not recognized by a heteronormative discourse that considers that only two sexes can exist. In fact, in absolute/given space, the processional space has been produced as "naturally" heterosexual through repeated, regulated, and normed performative acts. In other words, it is assumed (1) that the identity category "woman" is equally applicable to all women, thus overlooking the personal experiences and particular circumstances of each woman; (2) that this "woman" exists in opposition to the identity category "man" (which is also applicable to all men); and (3) that both identities form a closed and unquestionable whole.

Furthermore, "being a woman" is also defined by the performative act of clothing (shawl, black or white skirt, black or white blouse, low shoes, stockings), the devotion to specific images, and the respect given to the established processional order. In this sense, trans women who participate (when they dare to do so) comply with the performative act of gender, while at the same time subverting the imposed rules of binarism. Likewise, many female bearers, despite knowing that any expression of sensuality is forbidden, seek ways to subvert this norm by, for instance, wearing high heels, putting on make-up, fixing their shawl in a certain way, pulling their skirts above the knee, or putting on black yet embroidered stockings or black translucent blouses. As it is also the case with the cucurucho's tunic, for female bearers, their dress—and particularly so their shawl—is both a hallmark and an expression of themselves. The shawl is a polyvalent sign of (re)codified femininity: covering one's face with a black shawl is an external mark conveying pain, mourning, and grief; yet it is also used to communicate sensuality by, for instance, choosing to wear a shawl with certain embroideries or placing the shawls on combs to highlight the bearers' hairstyles.

33 Interview 25 April 2017, member of the Association of la Candelaria and Brotherhood of la Recolección.

34 Interview 5 May 2017. Interview with cucurucho. 
Going beyond established places and norms is also what some women advocating for their participation in the associations of the Passion do. When I asked them about their reasons for joining guilds, brotherhoods, or associations, they repeatedly mentioned that, besides devotional motives, they were searching for a place of their own. What is interesting about this is that, as female devotees-bearers, the processional space that was once forbidden to them is now conceived, in some cases, as a safe and liberating space. As a member of the Candelaria Association put it:

To me, that meant giving myself my space and saying "well, you're going to do what you like". When I separated with my partner, I got into the University, I got into Candelaria [brotherhood], I started doing the things that I had pending on my life list, things that were a gift from me, to me. And this is one of them. ${ }^{35}$

Interviews with women that have an active part in brotherhoods or associations (among them, a director of the brotherhood) show that women have used their participation in rituals related to the Holy Week as a strategy to form or strengthen networks of information and solidarity among women, and, in some cases, to transgress the patriarchal order in multiple and diverse ways. For instance, during preparations for Lent 2017, the women of the Brotherhood of Sorrows of the Temple of la Recolección took charge of selling the shifts, a move that put them in a position of power not only because it involves handling money, but also because selling shifts is regarded as one of the most prestigious committees. That year, however, the church's parishioners strongly criticized how "the women" handled the sale, arguing that the waiting lines were too long, thereby delaying the whole process and creating unnecessary tensions among parishioners. As is true of all brotherhoods and associations of the Passion, this Brotherhood also has a Facebook page where information about the organization, as well as pictures; comments; and news about events, shift sales, and the like, can be found ${ }^{36}$. In this particular case, most angry comments on the excessive duration of the shifts' sale criticized the women administrators' lack of experience and incompetence: "if they don't know how to do it, they are better off leaving it to the men." ${ }^{\prime 37}$

What the comments did not mention, however, was said in the inner circles of the guilds and brotherhoods of Guatemala City: that the long lines during the shift sale were in fact the consequence of the women of la Recolección not having been given the space where the sale is usually organized. The reason for this was that the women had fully funded the renovation of the Virgin's float and the men's brotherhood, seeing the improvements and how great it looked, wanted to debut it before Palm Saturday; that is, before the day women traditionally take the Virgin's float out for the first time during Holy Week celebrations. The women considered that the men did not have the right to do so and, in retaliation, the latter, who have control over the big space where shifts are usually sold, did not allow the women to use it, thereby forcing them to rent a much smaller space where the long line of parishioners could not be properly handled. This has not been the only retaliation, but it eloquently illustrates the internal struggles that occur when women transgress the patriarchal order of the processional organization and threaten the spaces of masculine power. The women that I interviewed agree that it has not been easy to occupy those spaces, and that it has in fact taken years and caused several conflicts. As Moncó (2009) points out, the growing participation of women in the

35 Interview 24 April 2017. The words in italics were emphasized by the interviewee.

36 https://www.facebook.com/Hermandad-de-Dolores-Templo-de-la-Recoleccion-155202021264700/.

37 Comment under the post about shift sales in the aforementioned page. In October 2017, the preparation for the shift sale for Easter 2018 was announced again through Facebook, and critical comments with a misogynistic tone regarding the 2017 sale can still be read: “They set the date so early because they won't be ready, so they'll change it and by the time Lent comes they will be able to deliver the shifts and there will still be a line! For sure! \#NataliaHandTheBrotherhoodOver \#YouCantDealWithThatCheese"; "Let us know in time if you're unable to hand out shifts, as it happened last year that you posted that it would happen at a certain time and we were in line for nothing; only to find out that you posted or put a sign a few minutes later saying that the delivery will be in the afternoon"; "Over the last years this shifts' delivery has been a disaster, let's see if now they actually manage to do it efficiently and in a good way" (Facebook Page of the Brotherhood of Sorrows of the Temple of la Recolección). 
associations' leadership is less questioned if they associate it with the fulfillment of a religious ritual. It is, to put it somehow, an occupation that is "permitted." Yet even if it has been several decades, at least in the associations and brotherhoods of Guatemala City, since women started to participate as full-fledged members, they still find opposition and resistance, especially so when their behavior or actions are perceived as encroaching on men's traditional spaces and power.

Deliberate adherence to brotherhoods, guilds, or associations thus echoes other dynamics that question the confinement of women to certain roles within the church, as well as the conception of the religious as an oppressive space. The latter issue was made evident throughout the long conversations I had during 2017 with various female bearers, guild members, and collaborators who also had a stable job. The goal of these interviews was to understand in a wider sense their adherence to and role within the brotherhoods organized by different parishes in Guatemala City. The information I gathered combines both their stories about how they became interested in the associations and how they ended up joining them, as well as their descriptions of the particularities of the celebration of Holy Week in their parishes. ${ }^{38}$ In this section, I want to specifically highlight how the involvement of women in a salaried job that allows them a certain margin of economic independence, makes it easier for them to be accredited as directors in associations and as active participants in special commissions. Many women take part in religious associations not because they are merely following their husbands or partners, but because it is their own choice, a choice that has been reassured by the work accomplished inside and outside the church.

These women, along with those women who try to "usurp" the place destined to male bearers by wrapping up their breasts, the gay parishioners that de facto occupy a place from which they are excluded in the religious discourse of the institutional church, and the trans parishioners that express their deep devotion by aspiring to carry the float of the Virgin Mary, transgress/undo gender norms in diverse ways. In the procession, these norms (such as the "adequate" way to dress) are always subjected to resignification and negotiation, thereby reorganizing relationships within the religious space itself.

\section{Final Reflections}

By focusing on gender relations, we have seen how the process of organizing the processional space through diverse logics and social dynamics constructs a division of the world in binary terms (inside/outside, sacred/profane, public/private) that not only produce gender differentiations, but also raise the question of what being a woman or a man means in those spaces. Brotherhoods and guilds have historically been male organizations where hierarchies and forms of male subjectivity and sociability could incontestably be represented and developed. Even if women have been gaining ground within the processional space and other Lenten activities, the asymmetries and differences constructed based on gender continue to reproduce. We could say that processions are, indeed, "meeting places" (Massey 1994) that intensify social relations that come from beyond and go beyond the processional space itself. On the one hand, gender relations are not only expressed and (re)produced in this space: they also "inhabit" it (Sundstrom 2003); on the other hand, however, this space is open because it is formed by social relations that always go beyond it. It can thus be said that there is no such thing as a perpetual or everlasting processional space, just as there is no such thing as a single identity that binds everyone together in one single place.

Moreover, gender differences are (re)produced in constant tension between the multiple ways of "doing", "performing", and "undoing" gender. In this article, my main concern has been to move beyond studies on gender and religion whose the main focus of analysis is showing how

38 They gave me information about the organization of the processions, the commissions that are formed, what is done in a procession and around which figures, the relationships within guilds and between brotherhoods, the spaces occupied by women, the relationships with the cucuruchos, etc. 
gender differences are reified in religious spaces, thereby legitimizing hegemonic masculinity and the patriarchy. As (Lugones 1987; Hooks [1990] 2015) have noted, the way in which space has been traditionally understood in terms of hegemonic masculinity leaves little room for identifying the agency of social subjects in the process of gender construction. Likewise, this framework of analysis hinders the possibility of outlining and further understanding the multiple ways in which normative gender relations are questioned in everyday life. In this sense, spaces that reflect gender dynamics ${ }^{39}$ (such as urban religious spaces) can also be analyzed as environments in which power relations are subtler and more complex than what they seem to be when understood only through the lens of difference and binarism.

In this article, I have shown how social subjects navigate the processional space while concurrently negotiating the (re)production of the normative gender identities they inhabit. Following Lefebvre (1974), I have also identified the interrelation between perceived, conceived, and lived space (his conceptual triad) in what I have called "the Lenten space". Moreover, in this ethnographic account, I have analyzed the relation between the construction of space and the construction of subjectivities, thereby showing the problematic aspects of limiting our understanding of the construction of gender "identity" in terms of boundary or division (as the rope would be). In particular, I have been interested in showing that the construction of gender differentiation goes beyond the mere spatial metaphor and therefore should be regarded as a social process that cannot be reduced to a boundary understood as the limit that defines who is inside or outside, who belongs, and who does not. Bourdieu (1980) once noted that "the boundary, that juridical product of delimitation, produces cultural difference as much as it itself is the product of that difference" (Bourdieu 1980, p. 66). For him, drawing a boundary thus involves exercising power in/over space, thereby setting a hierarchy between "us" and the "others". What I have seen throughout my ethnographic incursion, however, is that, in the space and time of Lent, such allegedly stable hierarchies are not homogeneous, inflexible, or based on fixed identities and, therefore, not totally closed to the other or to change. In other words, what I have observed raises questions about essentializing the procession as a space of belonging. In fact, the category of boundary becomes problematic when analyzing religious spaces given that these are much more malleable and flexible than what a simplistic separation between belonging or not belonging might indicate. For instance, the case of trans parishioners shows how one can be both inside and outside in different temporalities or belong on different levels. In this sense, trans parishioners do not read the processional space only in terms of exclusion, but rather live it as a space in which they express themselves in a different way and without being completely amalgamated with the female bearers or the cucuruchos. Additionally, since they do not try to define their participation in terms of belonging or non-belonging to such spaces, we cannot even say that we are talking about diffused limits.

It can thus be concluded that the street through which the procession passes should be understood as an ambivalent space given that even if there is an established order, this very same order is also subverted by the participants' everyday practices, as well as the atmosphere and the environment on the street itself. It can thus be said that the processional space itself is perpetually produced and reproduced: parishioners repeatedly reinscribe what is historically given (doing gender), but also recreate elements of gender differentiations (performing gender), and negotiate and subvert them (undoing gender).

It is thus necessary to rethink the hegemonic binary vision about femininity and masculinity. What I have found is that within the space of the Holy Week, this vision, even if reaffirmed, is also inhabited and questioned in different ways. These practices permanently question the usefulness/validity of the dualistic vision that, on the one hand, aligns masculinity with the public sphere, authority over the family, and the common good while, on the other hand, relegates femininity to the domestic sphere and the realm of private interests. I instead suggest that the organization of

39 The term used by Löw and Lawrence-Zúñiga (2001) is gendered spaces. 
the Holy Week space must be understood contextually; that is, as permanently reconfiguring gender relations beyond simplistic binary oppositions.

Funding: This research received no external funding.

Conflicts of Interest: The author declares no conflict of interest.

\section{References}

Bondi, Liz, and Joyce Davidson. 2005. Situating Gender. In A Companion to Feminist Geography. Edited by Lise Nelson and Joni Seagear. Hoboken: Blackwell Publishing Ltd., pp. 15-31.

Bondi, Liz, and Damaris Rose. 2003. Constructing gender, constructing the urban: A review of Anglo-American feminist urban geography. Gender, Place and Culture. A Journal of feminist Geography 10: 241-57. [CrossRef]

Bourdieu, Pierre. 1980. L'identité et la représentation [Éléments pour une réflexion critique sur l'idée de région]. Recherche en Sciences Sociales 35: 63-72. [CrossRef]

Brusco, Elizabeth. 1995. The Reformation of Machismo: Evangelical Conversion and Gender in Colombia. Austin: University of Texas Press.

Butler, Judith. 2004. Undoing Gender. New York/London: Routledge.

Cantón Delgado, Manuela. 2001. La razón hechizada. Teorías antropológicas de la religión. Barcelona: Ariel.

Cantón Delgado, Manuela. 2004. Religiones Globales, Estrategias locales: Usos políticos de las conversiones en Guatemala. Estudios sobre las Culturas Contemporáneas 19: 87-108.

Castillo, Ana Luz, Solórzano Foppa Julio, García Lara Mario, and González María Luisa. 2012. El valor económico de la Semana Santa en Guatemala. Guatemala: Editorial Cultura.

Chaulón, Mauricio. 2014. Representaciones sociales y relaciones de poder en la Semana Santa guatemalteca: el caso de la asociación de devotos cargadores de la consagrada imagen de Jesús Nazareno de la Candelaria. Tesis de Maestría en Antropología Social. Guatemala: Escuela de Historia, USAC.

Connell, Catherine. 2010. Doing, undoing, or redoing gender? Learning from the workplace experiencies of transpeople. Gender and Society 24: 31-55. [CrossRef]

Driessen, Henk, and Willi Jansen. 2013. Staging Hyper-masculinity on Maundy Thursday: Christ of the Good Death, the Legion and Changing Gender Practices in Spain. Exchange 42: 86-106. [CrossRef]

Drogus, Carol Ann. 1997. Women, Religion, and Social Change in Brazil's Popular Church. Notre Dame: University of Notre Dame Press.

Fogelman, Patricia. 2006. El culto mariano y las representaciones de lo femenino: Recorrido historiográfico y nuevas perspectivas de análisis. La aljaba. Available online: http:/ / www.scielo.org.ar/scielo.php?script= sci_arttext\&pid=S1669-57042006000100011\&lng=es\&tlng=es (accessed on 28 October 2017).

Harvey, David. 1989. The Condition of Posmodernity. Oxford: Basil Blackwell.

Harvey, David, ed. 2004. Space as a key word. In Spaces of Neoliberalization: Towards a Theory of Uneven. Munich: Franz Steiner Verlag, pp. 93-118.

Hooks, Bell. 2015. Yearning: Race, Gender, and Cultural Politics. Edited by Bell Hooks. New York: Routledge. First published 1990.

Johnston, Linda, and Robyn Longhurst. 2010. Space, Place and Sex: Geographies of Sexualities. Lanham: Rowman \& Littlefield Publishers Inc.

Kong, Lily. 2001. Mapping 'new' geograpies of religion: politics and poetics in modernity. Progress in Human Geography 25: 211-33. [CrossRef]

Kong, Lily. 2005. Religious processions: Urban politics and poetics. Temenos Finnish Journal of Religion 41: 225-49. Lefebvre, Henri. 1974. La production de l'espace. Paris: Éditions Anthropos.

Lefebvre, Henri. 2013. La producción del espacio. Madrid: Capitán Swing Libros. First published 1974.

Löw, Setha M., and Denis Lawrence-Zúñiga, eds. 2001. Locating Culture. In The Anthropolog. Oxford: Blackwell Publishing, pp. 1-48.

Lugones, María. 1987. Playfulness, 'World'-Travelling, and Loving Perception. Hypatia 2: 3-19. [CrossRef] Luján Muñoz, Jorge. 1998. Breve Historia Contemporánea de Guatemala. México: Fondo de Cultura Económica.

Mariz, Cecilia Loreto, and María Campos Machado. 1997. Pentecostalism and Women in Brazil. In Power, Politics and Pentecostals in Latin America. Edited by Cleary Edward L. and Hannah Stewart-Gambino. Boulder: Westview Press, pp. 41-54. 
Martínez Lorea, Ion. 2013. Henri Lefebvre y los espacios de lo posible. Prólogo. In La producción del espacio. Edited by Henri Lefebvre. Madrid: Ediciones Capitán Swing Libros, pp. 9-30.

Massey, Doreen. 1994. A place called home? In Space, Place and Gender. Edited by Doreen Massey. Minneapolis: University of Minnesota Press, pp. 157-73.

Massey, Doreen. 2005. For Space. London: Sage Publications.

Massey, Doreen, and John Allen, eds. 1984. Geography Matters: A Reader. Cambridge: Cambridge University Press.

McDowell, Linda. 1983. Towards an understanding of the gender división of urban space. Environment and Planning D: Society and Space 1: 59-72. [CrossRef]

McDowell, Linda. 1992. Doing gender: Feminism, feminists and research methos in human geography. Transactions of the Institute of British Geographers 17: 399-416. [CrossRef]

Méndez Salinas, Luis. 2017. Lo que las imágenes-y sus encuentros- dicen de nosotros. Semana Santa 2017. Guatemala: Diario La Hora, p. 5.

Moncó, Beatriz. 2009. Maternidad Ritualizada: un análisis desde la antropología de género. Revista de Antropología Iberoamericana (AIBR) 4: 357-84. [CrossRef]

Peterson, Anna. 2001. The only way I can walk: Women, Christianity and Every Day life in El Salvador. In Christianity, Social Change and Globalization in the Americas. Edited by Anna Peterson, Manuel Vásquez and Philipp Williams. New Brunswick: Rutgers University Press.

Segato, Rita. 2008. La faccionalización de la república y el paisaje religioso como índice de una nueva territorialidad. In América Latina y el Caribe. Territorios religiosos y desafíos para el cambio. Aurelio Alonso (Comp.). Buenos Aires: CLACSO, pp. 41-81.

Sundstrom, Ronald. 2003. Race and Place: Social space in the production of human kinds. Philosophy E Geography 6: 83-95.

Ubico Calderón, Mario A. 1995. Historia de las cofradías de la Candelaria, especialmente la de Jesús Nazareno. Guatemala City: Tradiciones de Guatemala, Centro de Estudios Folklóricos, vol. 44, pp. 107-48.

Urquizú, Gómez, and Luis Fernando. 2009. Jesús de Candelaria en la devoción popular de la Ciudad de Guatemala. In Suplemento Cultural de Diario La Hora. Especial de Semana Santa. Guatemala: Diario La Hora.

Woodhead, Linda. 2001. The impact of feminism on the sociology of religion: From gender-blindness to gendered difference. In The Blackwell Companion to the Study of Religion. Edited by Richard K. Fenn. Oxford: Blackwell, pp. 67-84.

(C) 2019 by the author. Licensee MDPI, Basel, Switzerland. This article is an open access article distributed under the terms and conditions of the Creative Commons Attribution (CC BY) license (http://creativecommons.org/licenses/by/4.0/). 